\title{
Penicillium air mycoflora in postharvest fruit handling environments associated with the pear export chain
}

\author{
Ilonka Scholtz ${ }^{\mathrm{a}}$, Nazareth Siyoum ${ }^{\mathrm{a}}$, Lise Korsten ${ }^{\text {at }}$
}

University of Pretoria, Department of Plant and Soil Sciences, Plant Pathology laboratories, Pretoria, Gauteng, South Africa $^{\mathrm{a}}$

\# Address correspondence to Professor Lise Korsten, lise.korsten@up.ac.za

\section{Highlights}

- A standard for air quality of postharvest fruit environments is proposed.

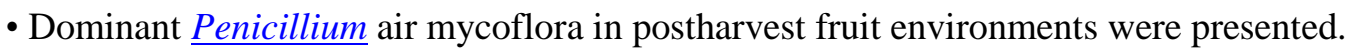

- Pathogenic Penicillium spp. in the air of fruit handling environment were profiled.

- Re-pack facilities had the highest air mycoflora counts than any other facility.

\begin{abstract}
Penicillium is a well-known airborne fungal contaminant that is prevalent in indoor air. In this study, the total air mycoflora was determined in postharvest fruit handling environments. The study included eleven indoor environments from the packhouse to the final retail outlet. Standard active and passive air sampling methods were used over a period of three years to obtain a profile of air quality. A total of 6047 and 5849 Penicillium colonies were counted of which 1123 and 508 isolates were obtained using active and passive sampling methods respectively. Ultimately, 25 dominant Penicillium spp. were identified from active air samples. The five most prevalent species isolated were: P. glabrum (31.88\%); P. expansum (14.18\%); P. crustosum (13.42\%); P. chrysogenum (10.35\%) and $P$. brevicompactum (10.25\%). Furthermore, a total of 22 Penicililum spp. were isolated from passive air samples with P. glabrum (23.72\%); P. italicum (16.45\%); P. brevicompactum $(14.22 \%)$; P. crustosum (13.80\%) and P. chrysogenum (11.76\%) being most prevalent. The presence of pathogenic Penicillium spp. in the air of fruit handling environments was profiled. Counts of total air mycoflora were
\end{abstract}


significantly higher in the re-pack facilities than in all other environments sampled and are significantly higher than the proposed baseline threshold value. This study clearly shows the importance of air quality in facilities that regularly handle different fruit types. Re-pack and retail facilities should therefore be cleaned more effectively to reduce the potential air inoculum that can induce decay of fruit at the market-end. Finally we propose an air quality standard for fresh produce environments.

Keywords: air; mycoflora; Penicillium; postharvest; fruit; environment.

\section{Introduction}

Aerosols are microscopic solid or liquid particles that are suspended in air (Pasquarella et al., 2000). Airborne particles containing living organisms known as bio-aerosols often represent a contaminant of indoor air (Kim et al., 2007). Viruses, fungal propagules, bacterial endospores, plant pollen and segments of plant tissues are constitutes of a bio-aerosol (Kalwasińska et al., 2012). Bio-aerosols are mainly sampled to evaluate the potential of environments to contaminate products due to the fallout potential of an area (Pasquarella et al., 2000). Physical (particle size, -density and -shape) and environmental factors (air currents, relative humidity and temperature) are the main parameters that affect bio-aerosol settling (Stetzenbach et al., 2004).

Air currents have been recognised as the principal physical factor responsible for the detachment and dispersion of fungal propagules, particularly Penicillium and Aspergillus, in indoor environments (Sivasubramani et al., 2004). Airborne fungal contaminants have progressively gained importance as health hazards and are also known to contribute to postharvest losses of fresh produce (Kakde and Kakde, 2012). The likelihood of Penicillium infection to occur through inoculum presence spores settling onto fruit surfaces and subsequent infection increases during optimal environmental conditions (Amiri and Bompeix, 2005). Other factors that influence the probability of Penicillium infection are the presence of high inoculum levels and environmental conditions favouring infection (condensate, 
vapour, temperature fluctuation), as well as respiration rate of fruit stored together, age of fruit and wounding frequency. The increased probability of Penicillium infection subsequently contributes to substantial postharvest losses due to decay (Amiri and Bompeix, 2005).

In general, the need to decrease pathogenic airborne microorganisms and their fallout has increased in various industries such as agriculture, health care, production and food processing plants (Shintani et al., 2004). Data accumulation and knowledge of microorganisms present within the air is of great importance before attempting to reduce microbial fallout (Yau et al., 2012). The approaches used for setting or reviewing microbial air quality standards vary between countries and industries. Differences between methodology, monitoring strategies, data interpretation and levels deemed acceptable prevent comparative analysis (Pasquarella et al., 2012 and Spickett et al., 2013). The need for the establishment of a national threshold value of fungal loads in the air (pathogenic and non-pathogenic fungi) in both indoor and outdoor air environments have previously been reported (Fischer and Dott, 2003). Fungi have been considered as useful biological indicators of indoor air quality to monitor the health of an environment or ecosystem (Cabral, 2010). A method to distinguish air quality in fruit handling environments has not been developed.

Active and passive air sampling methods are commonly used to monitor microbial aerosols in different environments (Altunatmaz et al, 2012 and Pasquarella et al., 2000). Active air sampling is used to determine total fungal loads in a specified volume of air, while passive air sampling provides a better representation of mycoflora that has the potential to settle onto fruit surfaces. The aim of this study was therefore to first determine the total air mycoflora in various postharvest fruit handling environments along the pear export chain using active and passive air sampling methods. This study further aimed to identify the ratio of Penicillium spp. within the air myco-environment, group the species. according to their postharvest disease causing potential and to develop a potential decay 
indicator (pdi) to monitor pathogenic Penicillium spp. in fresh produce environments. Finally to propose a more realistic air quality standard for fresh produce handling facilities.

\section{Materials and methods}

\subsection{Sampling approach and selected methods}

Air myco-environments were monitored by using both active- and passive air sampling methods. Active air sampling was done by using an automated SAS SUPER $100^{\mathrm{TM}}$ Compact Surface Air System ${ }^{\circledR}$ (PBI International, Italy) to collect airborne fungi by means of impaction on $65 \mathrm{~mm}$ malt extract agar (MEA) (Merck, Johannesburg) contact plates. Passive air sampling was performed by exposing $90 \mathrm{~mm}$ MEA settle plates to the environment for 20 mins. Air sampling was conducted locally (SA) and internationally (UK) over three years to achieve a reasonable profile of air quality in various facilities following the pear export chain. Local sampling areas included two commercial large scale pear packhouse facilities, at least three regular- and controlled atmosphere storage rooms at each packhouse and an export fruit container before packing pallets with pear fruit cleared for export. International sampling areas sampled included the same fruit export container after opening on the overseas market (average of 21 days later), two fresh fruit re-pack facilities handling the exported fruit, at least two cold storage rooms containing amongst others pears at each re-pack facility, a distribution centre (various fruit and vegetables ready for retail sales) and a retailer outlet where the pears are temporarily stored and displayed for sales. Between nine and twenty air samples were collected (depending on the size of the room) at randomly selected points in all the facilities sampled. Points and number of samples collected per room were the same for active and passive sampling. Active air samples were collected from the corners of a specific room and the sampler was directed inward towards the centre of the facility. The automated air-sampler was always held at the same height (one metre) above the ground. A total of 1380 air sampling plates were obtained (834 from active air sampling and 546 from passive air sampling). Eleven facilities were selected for sampling in the supply 
chain. Table 1 indicates the number of samples taken for active and passive air in each major facility sampled following the pear export chain as well as the average temperature and humidity typically encountered in these environments.

Table 1: Areas sampled in the pear export chain and number of samples obtained from each area over three years as well as the average temperature and humidity typically encountered in these environments.

\begin{tabular}{lrrrr}
\hline \multicolumn{1}{c}{ Fumber of } & Number of & Average & Average \\
& Active air & Passive air & temperature & relative \\
& sampling plates & sampling & $\left({ }^{\circ} \mathbf{C}\right)$ & humidity \\
& & plates & & \\
& & & & $(\%)$ \\
\hline Packhouse facilities (SA) & 180 & 80 & 19.6 & 65.00 \\
CA coldstorage (SA) & 144 & 68 & 3.85 & 79.60 \\
RA coldstorage (SA) & 200 & 88 & 2.9 & 73.75 \\
Container before export (SA) & 13 & 13 & 13.75 & 65.55 \\
Container after export (UK) & 15 & 15 & 8.5 & 79.9 \\
Receival area (UK) & 18 & 18 & 7.8 & 72.9 \\
Re-pack facilities (UK) & 57 & 57 & 20.9 & 55.3 \\
RA coldstorage (UK) & 102 & 102 & 4.6 & 71.1 \\
Distribution centre (UK) & 69 & 69 & 11.2 & 66.5 \\
Retail storage (UK) & 18 & 18 & 19.1 & 45.5 \\
Retail display (UK) & 18 & 18 & 19.1 & 68.5 \\
\hline Total & $\mathbf{8 3 4}$ & $\mathbf{5 4 6}$ & & \\
\hline
\end{tabular}

2.2. Sample processing and determining total air mycoflora loads

All air sampling plates were incubated at $25^{\circ} \mathrm{C}$ for approximately five days directly after sampling and transportation. Colony forming units per cubic metre of air $\left(\mathrm{CFU} / \mathrm{m}^{3}\right)$ and per $20 \mathrm{mins}(\mathrm{CFU} / 20 \mathrm{~min})$ were calculated based on total viable counts (TVC) of mycoflora for active and passive air sampling respectively. Even though no international consensus exists on limits for microbial contamination, the standard index of microbial air contamination in environments as described by Pasquarella et al. (Pasquarella et al., 2000) was used in this study as benchmark value to determine the microbial air quality. Penicillium colonies that were visually distinctive from each other (colour, texture, reverse 
colony colour etc.) were counted and recorded for each sample. Conidia was isolated from a single visually distinctive Penicillium isolate per sample and purified on $65 \mathrm{~mm}$ MEA plates for further identification.

\subsection{Identification of Penicillium species and data analysis}

Methods used for quantification, isolation, grouping and identification of isolated Penicillium spp. were described in Scholtz \& Korsten (Scholtz and Korsten, 2016). Penicillium colonies were counted and isolates were grouped according to similar cultural characteristics such as: colony size, color, texture and formation; mycelia coloration and formation; reverse plate coloration and the production of exudates. DNA was extracted from representative isolates using DNeasy® Plant Mini Kit from Qiagen (Southern Cross Biotechnology, Johannesburg). Amplification of a partial beta-tubulin ( $\beta$-tubulin) gene region was performed using Bt2a (5'- GGT AAC CAA ATC GGT GCT GCT TTC - 3') and Bt2b (5'ACC CTC AGT GTA GTG ACC CTT GGC - 3') primers (Glass and Donaldson, 1995). The $\beta$-tubulin PCR product was digested with the $B f a I$ (isochitzomer - FspBI) restriction enzyme according to the manufacturer's specifications. Isolates were grouped according to similar base pair sizes on PCR-RFLP gels and selected isolates were sequenced for identity confirmation. Potential decay indicator (pdi) organisms ( $P$. crustosum, $P$. digitatum, P. expansum, $P$. italicum and $P$. solitum) were furthermore selected to determine the decay-causing potential of air within the eleven facilities sampled in the pear export chain. Selection of pdi was done from known pathogenic isolates found in this study i.e. $P$. digitatum, $P$. crustosum, $P$. expansum, and $P$. solitum. These species were described as pathogenic and to cause green and blue mould on pears (Louw and Korsten, 2014). In addition, the other well known citrus pathogen $P$. italicum were also included in this study based on observed symptomatic citrus fruit present in the re-pack facilities at the time of this study. The five selected pathogenic Penicillium spp. were considered as pdi in fresh fruit supply chains and indicators of unsanitary conditions that can contribute to market-end rot. Colony counts per plate for each of the eleven 
sampling areas in the pear chain were used to calculate prevalent Penicillium spp. as was obtained from active and passive air sampling methods.

\subsection{Statistical analysis}

The number of organisms counted on the surface of the contact plates obtained for active air samlples were corrected for the statistical possibility of multiple particles passing through the same hole. Correction Tables are given in the SAS SUPER $100^{\mathrm{TM}}-$ microbiological monitoring of the environment, instruction manual. The probable count $(\operatorname{Pr})$ was then used to calculate the colony forming units (CFU) per cubic metre of air sampled.

The following formula was then used according to the manufacturer requirements of the SAS SUPER $100^{\mathrm{TM}}$ automated air sampler to calculate results obtained for active air samples:

$$
\mathrm{X}=(\operatorname{Pr} \mathrm{x} 1000) / \mathrm{V}
$$

$\mathrm{V}=$ volume of sampled air; $\mathrm{r}=\mathrm{CFU}$ counted on $55 \mathrm{~mm}$ contact plates; $\mathrm{Pr}=$ probable count obtained by positive hole correction; $\mathrm{X}=\mathrm{CFU}$ per 1000 litres $\left(=1 \mathrm{~m}^{3}\right)$ of air.

Data of active and passive air samples collected over time from various locations, areas and atmospheres was tested for normality using Shapiro-Wilk test with SAS statistical software (SAS Institute Inc. 1999. SAS/STAT User's Guide, Version 9, $1^{\text {st }}$ printing, Volume 2. SAS Institute Inc, SAS campus Drive, Cary, North Carolina 27513.). Data was not normally distributed and analysis of variance (ANOVA) was performed using non-parametric analyses with GenStat (GenStat release 7.22 DE, 2009, Discovery Edition 3). Kruskal Wallis test was done to assess significant difference among samples. Mann-Whitney test was used to evaluate significant difference between two samples. Mean ranks were compared for significant differences at $\mathrm{p}<0.05$. 


\section{Results}

\subsection{Total mycoflora obtained from active air samples}

The median microbial count obtained using the active air sampling method over the three year period taking all the facilities into account was $330 \mathrm{CFU} / \mathrm{m}^{3}$. Interrestingly facilities sampled in SA resulted in a total microbial count median value of $172 \mathrm{CFU} / \mathrm{m}^{3}$ while the $\mathrm{UK}$ was $505 \mathrm{CFU} / \mathrm{m}^{3}$ (Fig. 1). The highest counts were obtained from re-pack facilities in the UK with a median value of $2220 \mathrm{CFU} / \mathrm{m}^{3}$. The lowest counts obtained from active air samples were $63.3 \mathrm{CFU} / \mathrm{m}^{3}$ from RA coldstorage facilities in SA. The coldstorage facilities had significantly lower microbial counts than packhouse areas in SA at a $5 \%$ significance level.

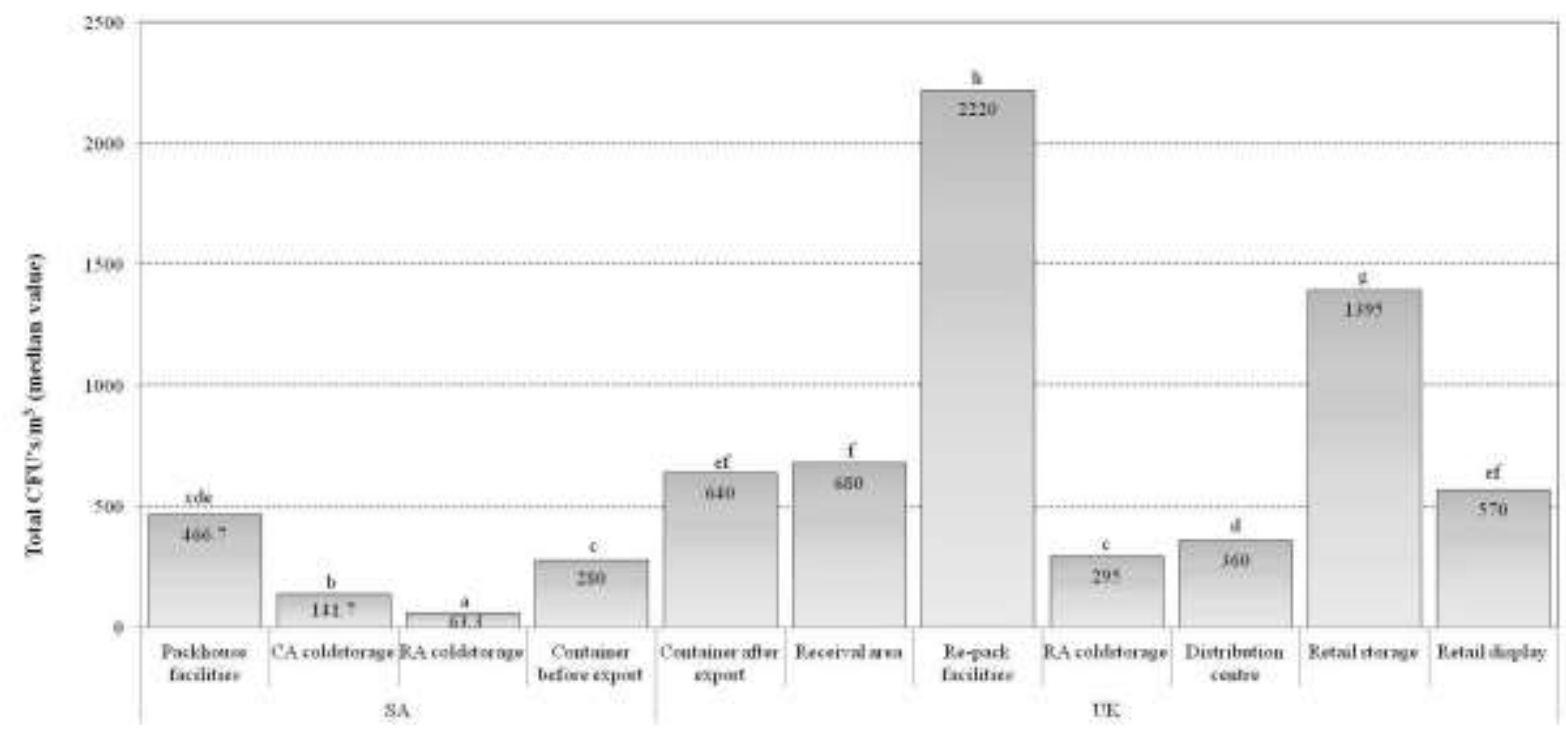

Figure 1: Total microbial counts (median values) obtained from active air samples (65mm malt extract agar contact plates) in various postharvest fruit handling facilities following the pear export chain from SA to the UK during three sampling years. Facilities sharing same letters did not differ significantly (mean ranks were used to compare significant differences at $\mathrm{p}<0.05)$. 


\subsection{Total mycoflora obtained from passive air samples}

The settle plate method (passive air) used in this study showed a median microbial count of 35 CFU/20 min for the overall study. Fresh produe handling facilities in SA and the UK had microbial loads of 28.0 and $37 \mathrm{CFU} / 20$ min respectively. The re-pack facilities in the UK also had the highest median counts (300.00 CFU/20 min) compared to the packhouses (9 CFU/20 min) in SA (Fig. 2). Re-pack facilities in the UK were the only facilities that had significantly higher microbial counts for passive air than any other facility sampled in this study (Fig. 2).

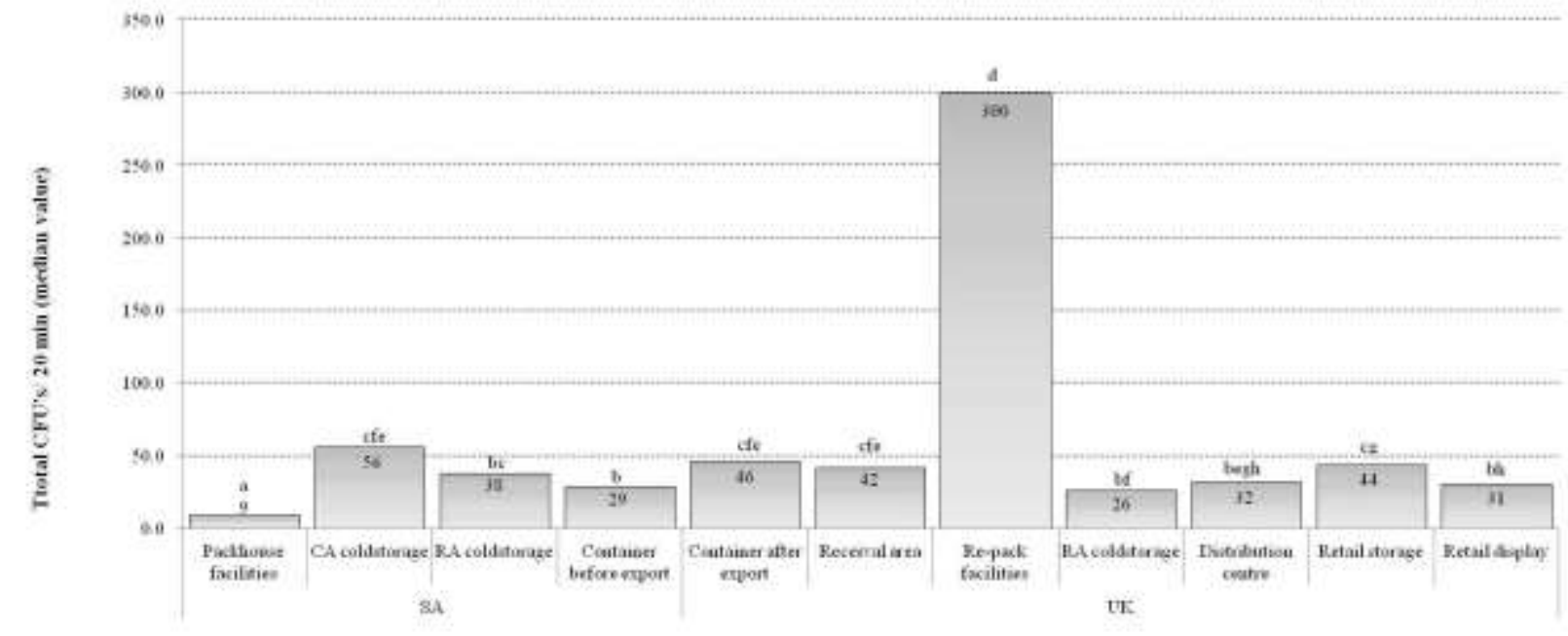

Figure 2: Total microbial counts (median values) obtained from passive air samples (65mm malt extract agar contact plates) in various postharvest fruit handling facilities following the pear export chain from SA to the UK during three sampling years. Facilities sharing same letters did not differ significantly (mean ranks were used to compare significant differences at $\mathrm{p}<0.05)$

3.3. Identity, diversity and prevalence of Penicillium species obtained from active air samples In total 20889 microbial colonies were obtained from active air samples over three sampling seasons. Of this 20889 colonies obtained, 6047 were identified as Penicillium. Therefore 28.9\% of microbes 
obtained from active air samples were Penicillium species. From these total Penicillium colonies, 1123 isolates were obtained and subsequently grouped into 282 morphological groups.

20964 microbial colonies were obtained from all passive air samples obtained during sampling. 5849 colonies of the total microbial counts were Penicillium species. Therefore $27.9 \%$ of the total microbial population obtained from passive air samples were Penicillium species. From these Penicillium colonies, 508 isolates were obtained and subsequently grouped into the 282 morphological groups as described previously.

Table 2: Diversity of Penicillium species isolated from fruit handling environments using active and passive air sampling methods.

\begin{tabular}{|c|c|c|}
\hline Sample source & Penicillium species & Prevalence $(\%)$ \\
\hline \multirow[t]{16}{*}{ Active air } & P. glabrum (Wehmer) Westling & 31.88 \\
\hline & P. expansum Link & 14.18 \\
\hline & P. crustosum Thom & 13.42 \\
\hline & P. chrysogenum Thom & 10.35 \\
\hline & P. brevicompactum Dierckx & 10.25 \\
\hline & $* * P$. italicum Wehmer & 7.30 \\
\hline & P. polonicum K. M. Zalessky & 3.29 \\
\hline & P. commune Thom & 1.62 \\
\hline & ${ }^{* *} P$. decaturense Peterson, Bayer and Wicklow & 1.30 \\
\hline & **P. biolowienzense K. M. Zalessky & 1.02 \\
\hline & $* * P$. solitum Westling & 0.72 \\
\hline & P. roquefortii Thom & 0.64 \\
\hline & **P. palitans Westling & 0.56 \\
\hline & **P. nordicum Dragoni and Cantoni & 0.45 \\
\hline & **P. spinulosum Thom & 0.35 \\
\hline & **P. echinulatum Raper and Thom & 0.27 \\
\hline
\end{tabular}


**P. digitatum (Pers.: Fr.) Sacc $\quad 0.19$

*P. minioluteum Dierckx $\quad 0.18$

**P. waksmanii K. M. Zalessky $\quad 0.17$

*P. corylophilum Dierckx $\quad 0.14$

**P. sizovae Baghd $\quad 0.11$

*P. griseofulvum Dierckx $\quad 0.06$

*P. sclerotiorum J. F. H. Beyma $\quad 0.03$

*P. angulare Peterson, Bayer and Wicklow $\quad 0.02$

other Penicillium spp. $\quad 1.49$

$\begin{array}{lll}\text { Passive air } & \text { P. glabrum } & 23.72\end{array}$

$\begin{array}{ll}* * P . \text { italicum } & 16.45\end{array}$

$\begin{array}{lr}\text { P. brevicompactum } & 14.22\end{array}$

$\begin{array}{ll}\text { P. crustosum } & 13.80\end{array}$

$\begin{array}{ll}\text { P. chrysogenum } & 11.76\end{array}$

$\begin{array}{ll}P . \text { expansum } & 4.66\end{array}$

**P. digitatum $\quad 3.92$

**P. biolowienzense $\quad 2.69$

$\begin{array}{ll}\text { P. polonicum } & 1.50\end{array}$

**P. echinulatum 1.11

$\begin{array}{ll}* * P . & \text { waksmanii }\end{array}$

$\begin{array}{ll}* P \text {. angulare } & 1.04\end{array}$

$\begin{array}{ll}* * P . \text { palitans } & 0.60\end{array}$

$\begin{array}{ll}\text { P. commune } & 0.58\end{array}$

$\begin{array}{ll}* * P \text {. decaturense } & 0.35\end{array}$

$\begin{array}{ll}* * P \text {. solitum } & 0.31\end{array}$

$\begin{array}{ll}* P \text {. chermesinum Biourge } & 0.21\end{array}$

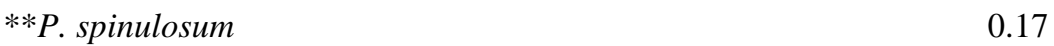

$\begin{array}{ll}\text { P. roquefortii } & 0.14\end{array}$ 
* species isolated only in SA

** species isolated only in UK

3.4. Penicillium potetial decay indicator species obtained from active air samples

In order of most to least prevalent pdi isolates obtained from postharvest fruit handling facilities sampled included $P$. expansum, $P$. crustosum, P.italicum, $P$. solitum and $P$. digitatum with median values of $3.5 \mathrm{CFU} / \mathrm{m}^{3}, \quad 3.5 \mathrm{CFU} / \mathrm{m}^{3}, \quad 4.5 \mathrm{CFU} / \mathrm{m}^{3}, \quad 1 \mathrm{CFU} / \mathrm{m}^{3}$ and $2 \mathrm{CFU} / \mathrm{m}^{3}$ respectively. Fluctuations in numbers of these organisms present within the facilities are presented in Figure 3 . It was noted that citrus pathogens $P$. italicum and $P$. digitatum were more prevalent in the UK facilities (Figure 3) compared to the SA facilities. However, none of the indicator Penicillium species were isolated in the retail storage and retail display areas in UK. 

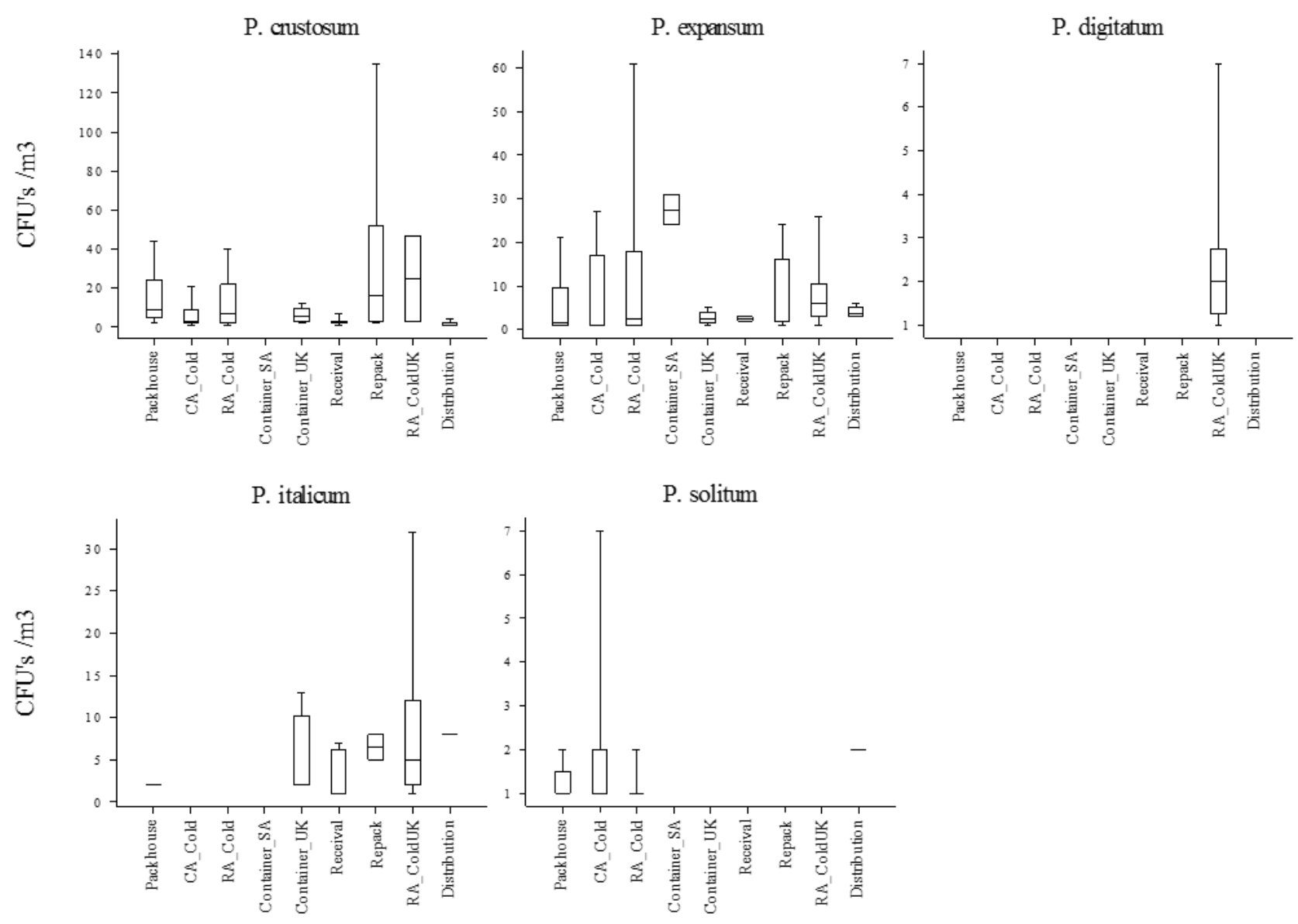

Figure 3: Penicillium colony counts (median value) for five pathogenic species (P. crustosum, P. expansum en $P$. solitum, P. digitatum and P. italicum) obtained from active air samples of various postharvest fruit handling facilities following the pear export chain from SA to the UK during three sampling years.

\subsection{Penicillium potential decay indicator species obtained from passive air samples}

In order to reflect the least prevalent organisms present in air using the passive air smapling method are P. crustosum, $P$. expansum, P.italicum, $P$. digitatum and $P$. solitum with median values of 6.5 $\mathrm{CFU} / \mathrm{m}^{3}, 7 \mathrm{CFU} / \mathrm{m}^{3}, 8 \mathrm{CFU} / \mathrm{m}^{3}, 6 \mathrm{CFU} / \mathrm{m}^{3}$ and $3 \mathrm{CFU} / \mathrm{m}^{3}$ respectively. None of the citrus pathogens ( $P$. digitatum and $P$. italicum) were isolated using the the passive air method in the sampled SA facilities (Figure 4). 

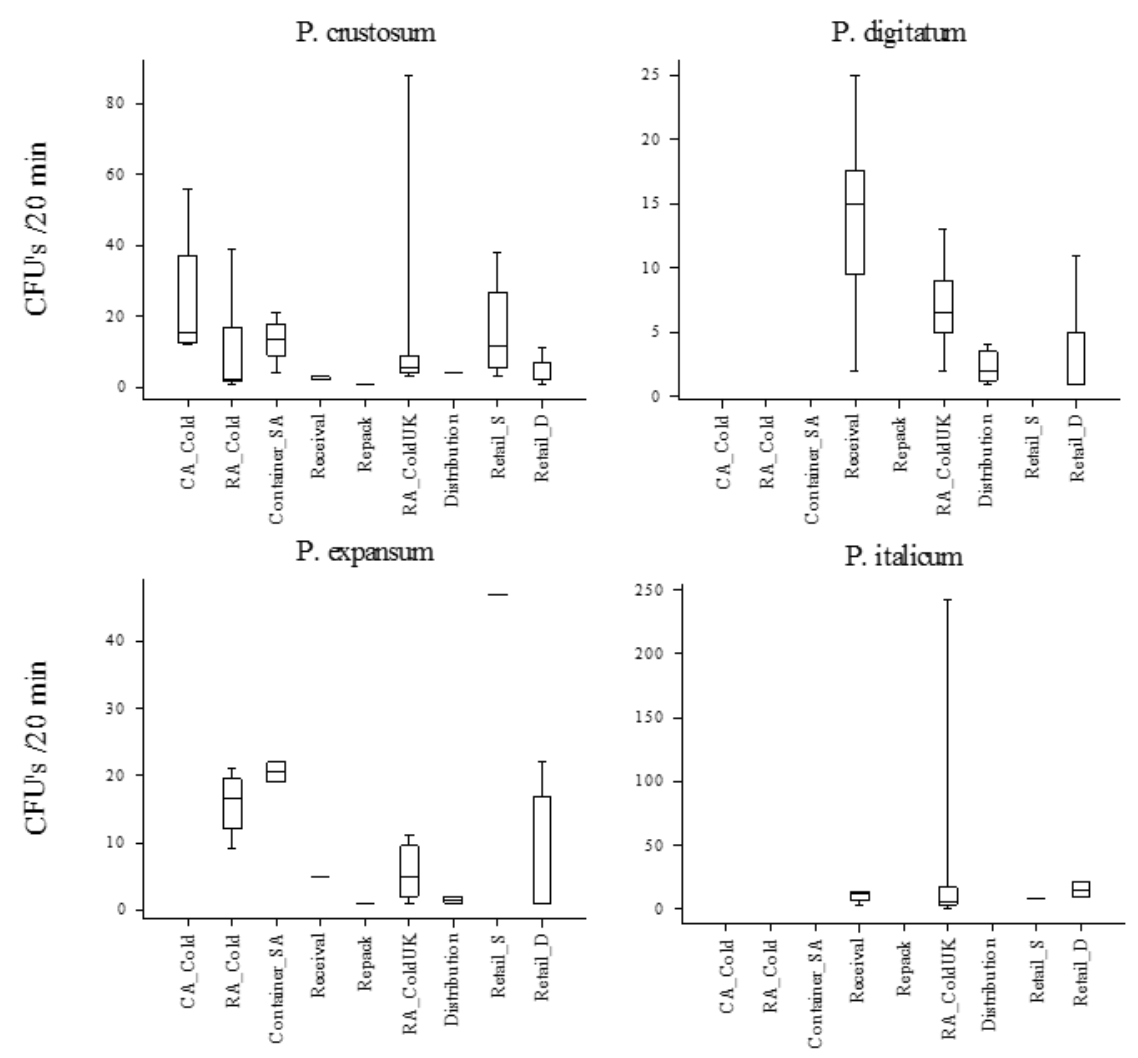

Figure 4: Penicillium colony counts (median value) for four pathogenic species (P. crustosum and P. expansum, $P$. digitatum and P. italicum) obtained from passive air samples of various postharvest fruit handling facilities following the pear export chain from SA to the UK during three sampling years.

\section{Discussion}

Our study highlighted the need to align different methodologies to attain a better perspective of air quality (Portnoy et al., 2004). Without a clear indication of methodologies used to consider air quality suitable for food handling environments, standards described by Pasquarella et al. (Pasquarella et al., 2000) for microbial contamination according to the European Union Good Manufacturing Practice (EU GMP) were used. Exceeding a limit of $200 \mathrm{CFU} / \mathrm{m}^{3}$ and $8.33 \mathrm{CFU} / 20 \mathrm{~min}$ for active- and passive air samples respectively, was therefore used as criteria in this study and exceeding these values was regarded as unacceptable air quality. However based on the current study an alternative index is proposed to reflect a more realistic environment for fresh produce handling environments. Based on the data obtained in this study (834 and 546 samples from active- and passive air sampling respectively) 
over a three year period it is proposed to use a more "fit-for-purpose" criteria for air quality monitoring in postharvest fruit handling facilities when using the active- and passive air sampling methods (330 $\mathrm{CFU} / \mathrm{m}^{3}$ and $35 \mathrm{CFU} / 20 \mathrm{~min}$ respecitively). Fresh produce handled from the farm-to-the-market are exposed to different environmental conditions and the raw product entering these environments contains a natural field microbial biome (Berg et al., 2014) that continuously shed microorganisms into the environment during sorting, grading, washing, packing etc. Air quality of fresh produce handling environment should therefore be measured against less stringent criteria compared to processed food environments $(16.7 \mathrm{CFU} / 20 \mathrm{~min})$ or even operating theatres in hospitals $(\leq 1.7 \mathrm{CFU} / 20 \mathrm{~min}$ and $\leq 10$ $\mathrm{CFU} / \mathrm{m}^{3}$ ) that have to by their very nature represent a close to sterile environment (Pasquarella et al., 2000).

The difference between the median mycoflora present as obtained in this study from active air and the recommended threshold value was found to be not as high as the variance between these two values for passive air. Unlike passive air sampling, active air sampling measures a specific volume of air and therefore results are more reliably comparable to the threshold value $\left(200 \mathrm{CFU} / \mathrm{m}^{3}\right.$ ) (Pasquarella et al., 2000). Even though the overall quality of air (obtained from active air samples) has higher mycoflora than the accepted limit proposed, cold storage facilities in this study were found within the required norm. This reflects a high level of facility hygiene which is aligned with the current criteria that the company complies with and is based on their GlobalG.A.P. risk assessment approach.

Our results indicate that more attention should be given to general sanitation of repack facilities since they displayed highest mycofloral count.The reason for the high microbial count in these facilities could be due to the quantity and the wide variety of fruit that passes throughthese facilities . Re-pack facilities in export destination markets handle different fruit types from various countries, which may contribute to the higher microbial count. It is also worthy to note that these facilities are not certified to any food safety management standard which is in total contrast to packhouses earlier on in the supply 
chain. Hence, intervention through certification of management systems could result in better air quality in the facility. At the time of sampling, it was noted that the air cooling system of the distribution centre (UK) had visual signs of fungal growth on the grid and filters (observation, unpublished data). It was furthermore noted that a pallet containing plums infected with Penicillium was standing in front of the air cooling system, thus blowing air over the product most likely dislodging fungal spores. Fungal spores collected from this hazard point were subsequently used to confirm pathogenicity on plums (Louw and Korsten, 2016). The total mycoflora counts in the distribution centre (UK) were however lower than what was expected, which may be accounted for the large open area. According to Lee and Liao (Lee and Liao, 2014), airborne fungal propagules accumulate easily in enclosed environments without sufficient ventilation. Therefore, the significant increase of mycoflora counts in export containers were as expected.

With the exception of cold storage areas, all other facilities were in the optimal temperature range for survival and growth of mycoflora. Perishable fresh foods are usually kept at temperatures of $0{ }^{\circ} \mathrm{C}$ to 15 ${ }^{\circ} \mathrm{C}$ depending on their nature and storage period during the various stages of the cold chain (production, storage, transport, distribution and sale). For pears specifically the recommended storage temperature is between $0{ }^{\circ} \mathrm{C}$ and $0.5{ }^{\circ} \mathrm{C}$ for up to one month of storage and up to $2{ }^{\circ} \mathrm{C}$ for long term storage (Kader, 2002) Optimal growth conditions for Penicillium spp. are between $10^{\circ} \mathrm{C}$ and $25^{\circ} \mathrm{C}$ and $>70 \%$ relative humidity (Cooley et al., 1998). The average cold storage temperatures mostly exceeded the recommended 0 to $2.0^{\circ} \mathrm{C}$ temperature range for pears in this study. The upper limit of $15{ }^{\circ} \mathrm{C}$ storage temperature for fresh produce was mostly exceeded in non-refrigirated areas such as re-pack, distribution and retail facilities. With the exception of the re-pack facilities $(55.3 \%)$ and retail storage areas $(45.5 \%)$, the relative humidity of all other facilities sampled was close to or exceeded $70 \%$ that favours fungal growth. Managing and keeping the storage conditions below the optimum range for Penicillium spp. would be complex in facilities that handle diverse fruit types. Therefore, strict 
sanitation programme should be applied in such facilities to minimize and keep microbial loads within the recommended standards and to control fruit decay.

Total CFU obtained from passive air (35 CFU/20 min) was four times higher than the threshold value selected for this study $(8.33 \mathrm{CFU} / 20 \mathrm{~min})$. Some criticism relating to passive air sampling (settle plates), is that the exact volume of air measured is unknown and settling is affected by the size and shape of particles and by the motion of the surrounding atmosphere (Pasquarella et al., 2000). Even though comparison of numbers obtained in this study to threshold values has some discrepancies, the margin of difference between these values cannot be dismissed. Passive air fallout is furthermore perceived as a direct indication of the contamination level of the surrounding surfaces and is therefore important to consider in context of fruit exposed to the air. The mycoflora counts within the fruit handling environment in this study were found to exceed the standard limits for acceptable sanitation maintenance levels. The only facility in this chain that had a significantly higher passive air CFU counts than the rest of the facilities was the re-pack area. It is therefore proposed that a more acceptable maximum CFU threshold limit be set for fresh produce environments in general but excluding the values obtained in this facility that was deemed exceeding the new proposed norm. Thus for passive air 33.5 CFU/20 min is proposed as a realistic threshold value for all environments in the chain. Due to the high microbial load, re-pack facilities can therefore be considered as a higher risk area in the chain and should be managed accordingly.

During sampling, it was noted that there is a lot of movement in the various areas throughout the day (unpublished data). Movement can generate air currents, which have been indicated as the principal physical factor causing detachment and dispersion of Penicillium propagules in indoor environments (Sivasubramani et al., 2004). Penicillium propagules may ultimately attach to fruit surfaces, infect the fruit and cause decay at the consumer-end of the chain. A study done by Amiri and Bompeix (Amiri and Bompeix, 2005) indicated that airborne spores of Penicillium are an important source of pome fruit 
contamination. In this study, Penicillium spp. accounted for approximately $30 \%$ of the total mycoflora in aerial environments of postharvest fruit handling facilities. The selected pdi species made up $38.8 \%$ and $39.3 \%$ of the total Penicillium population isolated from active and passive air samples respectively. It was previously reported that a low density of airborne Penicillium spores might cause decay especially during optimal disease development conditions contributing quantitative and qualitative postharvest losses (Amiri and Bompeix, 2005). The presence of these Penicillium pdi air inoculum in the fruit handling environments therefore poses a risk for infections near the market-end of the chain.

A general perception exists that even though $P$. digitatum and $P$. italicum (citrus pathogens) inoculum levels were high in the air of certain postharvest fruit handling areas in the export chain, it had no effect on non-hosts such as pears. Since Louw and Korsten (Louw and Korsten, 2014) could show that $P$. digitatum could cause extensive symptoms in pome fruit, it challenges previous assumptions that citrus pathogens do not affect pear quality. The inclusion of well-known citrus pathogens $P$. digitatum and $P$. italicum as part of the pdi organisms used in this study provided an insight into the dynamics of these species throughout aerial environments of the postharvest fruit handling facilities in the export chain. Pear pathogenic Penicillium pdi were more prevalent in the SA side of the export chain in comparison with the known citrus pathogens that were rarely found in pear packhouses. This can be because a higher number of different fruit types were handled in the UK part of the pear export chain and therefore affect the microbial dynamics of the air. The conclusion is that the more fruit types that is handled in one area, the higher the microbial population and diversity will be, since the microflora of each fruit is different and contribute to the air mycoflora through constant microbial shedding.

Using the passive air sampling method, few or no pdi were detected in the re-pack facilities (Figures 3 and 4). This could be because of the extensive movement and re-packing that was hapenning. A study done by Lehtonen and Reponen (Lehtonen and Reponen 1993), indicated that everyday household activities may cause significant changes in the number and types of airborne fungi. Their study 
furthermore showed that settled spores could easily become airborne through household activities, such as sweeping of floors. Handling of organic material was also shown to increase the numbers of airborne fungal spores in the environment. Similar types of activities in the packhouse and re-pack areas can have a significant effect on airborne Penicillium spore loads compared to spores that settle onto surfaces.

\section{Conclusion}

The lack of consensus on what constitute healthy hygienic air quality in fresh produce handling environments makes managing santation levels and reducing decay difficult. In this study fresh produce environments were monitered over a three-year period following export fruit i.e. pears, to develop a more realistic air mycoflora standard for postharvest fruit handling environments. Values of 330 $\mathrm{CFU} / \mathrm{m}^{3}$ and $35 \mathrm{CFU} / 20 \mathrm{~min}$. for active- and passive air sampling respectively, were found. Total microbial counts for both active and passive air sampling indicated that re-pack facilities towards the end of the chain have much higher CFU counts compared to all other facilities sampled and exceeded threshold the average values proposed in this study. The most common fungi found in the fresh produce environments were Penicillium species (30\% of total air mycoflora). A diversity of 25 and 22 different Penicillium spp. were obtained from active and passive air sampling respectively. Penicillium glabrum was the most frequently isolated species. Citrus and pear pathogens that were selected as pdi to assess air quality represented approximately $40 \%$ of the total Penicillium population. Of these pathogenic species $P$. expansum and $P$. crustosum were prevalent in the air of most of the fresh produce handling facilities. This represents a potential risk of cross-contamination of fruit towards the end of the supply chain. Future studies should focus on the link between Penicillium inoculum levels in aerial environments and decay at the retail-end. 


\section{Acknowledgments}

For financial support the authors would like to thank the National Research Foundation (NRF), Technology and Human Resources for Industry Programme, the South African Apple and Pear Producers Association (administered by Fruitgro Science), the Department of Science and Technology, Fresh Produce Exporters Forum, Postharvest Innovation Programme PHi and the University of Pretoria for grants and bursaries received during the study. The authors also would like to tank the farmers, packhouse managers, exporters, importers, re-packers, distiributioin centres and retailers allowing us to sample the premises.

\section{References}

Altunatmaz SS, Issa G, Aydin A. 2012. Detection of airborne psychrotrophic bacteria and fungi in food storage. Braz. J. Microbiol. 43:1436-1443.

Amiri A, Bompeix G. 2005. Diversity and population dynamics of Penicillium spp. on apples in preand postharvest environments: consequences for decay development. Plant Pathol. 54:74-81.

Berg G, Grube M, Schloter M, Smalla K. 2014. Unraveling plant microbiome: looking back and future perspectives. Front. Microbiol. DOI: 10.3389/fmicb.2014.00148.

Cabral JPS. 2010. Can we use indoor fungi as bioindicators of indoor air quality? Historical perspectives and open questions. Sci. Total Environ. 408:4285-4295.

Cooley JD, Wong WC, Jumper CA, Straus DC. 1998. Correlation between the prevalence of certain fungi and sick building syndrome. Occup. Environ. Med. 55:579 -584.

Fischer G, Dott W. 2003. Relevance of airborne fungi and their secondary metabolites for environmental, occupational and indoor hygiene. Arch. Microbiol. 179:75 - 82.

Glass NL, Donaldson GC. 1995. Development of primer sets designed for use with the PCR to amplify conserved genes from filamentous ascomycetes. Appl Environ Microbiol 61:1323-30. Kader AA. 2002. Postharvest Technology of Horticultural Crops. UCANR Publications, USA. 
Kakde UB, Kakde H. 2012. Incidence of post-harvest disease and airborne fungal spores in a vegetable market. Acta Bot. Croat. 71:147-157

Kalwasińska A, Burkowska A, Wilk I. 2012. Microbial air contamination in indoor environment of a university library. Ann. Agr. Env. Med. 19:25-29.

Kim KY, Park JB, Jang GY, Kim CN, Lee KJ. 2007. Assessment of Bioaerosols in the Public Buildings of Korea. Indoor. Built Environ. 16:465-471.

Lee S, Liao C. 2014. Size-selective assessment of agricultural workers' personal exposure to airborne fungi and fungal fragments. Sci. Total Environ. 466-467:725-732.

Lehtonen M, Reponen T. 1993. Everyday Activities and Variation of Fungal Spore Concentrations in Indoor Air. Int. Biodeter. Biodegr. 31:25-39.

Louw JP, Korsten. 2016. Postharvest decay of nectarine and plum caused by Penicillium spp. Eur. J. Plant Pathol. DOI 10.1007/s10658-016-0956-0.

Louw JP, Korsten L. 2014. Pathogenic Penicillium spp. on apples and pears. Plant Dis. 98: 590-598.

Pasquarella C, Pitzurra O, Savino A. 2000. The index of microbial air contamination. J. Hosp. Infect. 46:241-56.

Pasquarella C, Vitali B, Saccani E, Manotti P, Boccuni C, Ugolotti M, Signorelli C, Mariotti F, Sansebastianoa GE, Albertini R. 2012. Microbial air monitoring in operating theatres: Experience at the University Hospital of Parma. J. Hosp. Infect. 81:50-57.

Portnoy JM, Barnes CS, Kennedy K. 2004. Sampling for indoor fungi. J. Allergy Clin. Immun. 113:189-198.

Scholtz I, Korsten L. 2016. Profile of Penicillium species in the pear supply chain. Plant Pathol. Doi: 10.1111/ppa.12494. 
Shintani H, Taniai E, Miki A, Kurosu S. 2004. Comparison of the collecting efficiency of microbiological airsamplers. J. Hosp. Infect. 56:42-48.

Sivasubramani SK, Niemeier RT, Reponen T, Grinshpun SA. 2004. Assessment of the aerosolization potential for fungal spores in mouldy homes. Indoor air 14:405-12.

Spickett J, Katscherian D, Harris P. 2013. The role of Health Impact Assessment in the setting of air quality standards: An Australian perspective. Environ. Impact Asses. 43:97-103.

Stetzenbach LD, Buttner MP, Cruz P. 2004. Detection and enumeration of airborne biocontaminants. Curr. Opin. Microbiol. 15:170-174.

Yau YH, Chew BT, Saifullah AZ. 2012. Studies on the indoor air quality of pharmaceutical laboratories in Malaysia. International Journal of Sustainable Built Environment 1: 110-124. 